\title{
TERAPI TERTAWA TERHADAP TINGKAT STRES PADA LANSIA DI RW 06 KELURAHAN DARMO SURABAYA
}

\author{
Erika Untari Dewi \\ STIKES William Booth Surabaya, Jl. Cimanuk No 20 Surabaya Telp. 031-5633365 Email: \\ stikes_williambooth@ymail.com
}

\begin{abstract}
ABSTRAK
Stress berasal dari bahasa latin yang berarti keras (sticus) dan istilah stress diartikan sebagi kesukaran, kesusahan, kesulitan, atau penderitaan pada manusia terutama mental yang dengan menunjukan kekuatan, tekanan, ketegangan. Terapi Tertawa pada orang tua merupakan salah satu alternatif non farmakologis yang mudah dilakukan dan mudah digunakan namun menawarkan manfaat signifikan dalam mengurangi stres. Tujuan dari penelitian ini adalah untuk mengetahui Tingkat stres pada lansia di RW 06 Kelurahan Darmo Surabaya sebelum dan sesudah diberikan terapi tertawa. Penelitian ini menggunakan desain penelitian pre - eksperimental (one group pre - post test desing).diberikan selama 4 kali dalam seminggu dibagi menjadi 2 sesi yaitu ( 2 hari pre dan 2 hari post) sampel adalah 20 responden dengan stres.Hasil penelitian ini menunjukan bahwa sebelum dan sesudah dilakukan terapi tertawa terdapat penurunan tingkat stres.Hasil yang didapatkan peneliti sebelum terapi tertawa 14 orang kategori Tidak kebal dan setelah dilakukan terapi tertawa 12 orang kategori kurang kebal. Hasil analisa dari uji Wilcoxon di ketahui bahwa nilai $\mathrm{p}=0,000$ sehingga $\mathrm{H} 0$ ditolak, ini menunjukan ada pengaruh terapi Tertawa terhadap tingkat Stres pada Lansia di RW 06 Kelurahan Darmo Surabaya. Penelitian ini merekomendasikan perlunya Terapi Tertawa Untuk mengurangi Tingkat Stres.
\end{abstract}

Kata kunci: Lansia, Stres, Terapi Tertawa

\begin{abstract}
Stress comes from the Latin which means hard (sticus) and the term stress is defined as difficulty, distress, difficulty, or suffering by showing strength, stress, tension, or hard effort centered on things and people, especially human mental powers. Laughing therapy in the elderly is one nonpharmacological alternative that is easy to do and easy to use but offers significant benefits in reducing stress. The purpose of this study was to determine the level of stress in the elderly in RW 06 Village Darmo Surabaya before and after being given laughter therapy. This research uses pre-experimental research design (one group pre-post test desing). Provided for 4 times a week divided into 2 sessions (2 days pre and 2 post days) sample is 20 respondents with stress. The results of this study showed that Before and after the laughing therapy there is a decrease in stress level. Results obtained by researchers before laughing therapy 14 people category Not immune and after the laughter therapy 12 people less immune category. Results analysis of the Wilcoxon test in know that the value of $p=0.000$ so HO rejected, this shows the effect of laughter therapy on the level of stress in the elderly in RW 06 Kelurahan Darmo Surabaya. This study recommends the need for Laughing Therapy to Reduce Stress Level.
\end{abstract}

Keywords: Elderly, Stress, Laughter Therapy 


\section{PENDAHULUAN}

Lansia adalah tahap akhir perkembangan pada daur kehidupan manusia (Maryam, dkk. 2008). UU No.13 tahun 1998 mengatakan bahwa seseorang yang telah mencapai usia $\leq 60$ tahun disebut lansia. Dikatakan lansia apabila ada tanda perubahan yang terlihat pada fisik seperti keriput rambut beruban, gigi mulai ompong, pendengaran dan penglihatan mulai berkurang, mudah lelah, gerakan lamban dan kurang lincah, serta terjadi penimbuanan terutama diperut dan pinggul. Perasaan yang tidak berguna, mudah sedih, insomnia, stres, depresi, ansietas dan demensia juga merupakan perubahan psikologis yang sering dijumpai pada lansia. Dari beberapa masalah tersebut stres merupakan salah satu faktor yang paling tinggi untuk memicu kegagalan seseorang dalam mempertahankan keseimbangan terhadap suatu kondisi. Stres adalah respon adaptif dipengaruhi karakteristik individual atau proses psikologi, yaitu akibat dari tindakan, situas, atau kejadian eksternal yang menyebabkan seseorang mengalami perubahan fisik dan psikologis (Kreitner dan Kinicki, 2004). Menurut Claude Bernad, 1867 (Potter dan perry,1997) fungsi organisme sangat dipengaruhi oleh perubahan dalam lingkungan internal dan eksternal sehingga adaptasi terhadap stressor sangat penting untuk tetap bertahan. Stres bisa dipicu oleh stresor. Kegagalan dalam menyesuaikan diri dan mengatasi perubahan yang terjadi pada masa tua akan berdampak pada persepsi yang buruk dan muncul gejala - gejala seperti pusing, mudah lelah, sulit tidur, dan lain sebagainya. Data Word Health Organization (WHO) menunjukkan bahwa Indonesia berada di urutan 18 dalam jumlah lansia terbanyak di dunia. Sementara di Amerika serikat ada penambahan jumlah lansia yang diperkirakan 1.000 per hari, pada tahun 2001 berdasarkan hasil penelitian Kinsella dan Velkof. Jumlah lansia di Indonesia meningkat dari 7,28\% (15.262.199 jiwa) menjadi 7,97\% (17.767.709) dari tahun 2000 sampai tahun 2005 dan pada tahun 2010 meningkat juga menjadi 19.936.895 jiwa dengan presentase $8,48 \%$, (Padila, 2013). Dan jumlah lansia yang berada di Jawa timur adalah 4.113.847 orang atau sekitar $11 \%$ dari total penduduk Jawa timur AS (Birohumas.jatimprov,2015), di kota Surabaya jumlah lansia sekitar 300 ribu lansia, atau $10 \%$ dari total penduduk Surabaya. Dari hasil wawancara dan observasi kepada 7 lansia pada tanggal 2 Februari 2017 di RW 06 kelurahan Darmo kecamatan Wonokromo terdapat 3 lansia menyatakan tinggal sendirian dan lansia tersebut menyatakan hal yang mendorong dirinya untuk tetap beraktifitas sehari-hari yaitu untuk mencari kesibukan diwaktu senggangnya, tidak tergantung pada keluarganya atau orang lain dan tetap aktif dan sehat, lansia tersebut terkelompok kemandirian penuh yaitu mandiri dalam hal mengontrol berkemih, berpakaian, naik turun tangga, berjalan di jalan yang datar, berkebun, berdagang, makan, minum,mandi, BAB, BAK, dan bergerak tanpa bantuan keluarga atau orang lain. 4 lansia yang tinggal bersama dengan keluarganya, masuk dalam kelompok ketergantungan ringan yaitu masih mandiri dalam melakukan semua hal kecuali naik turun tangga. Masalah utama yang sering dijumpai pada lansia adalah menurunnya kemampuan fisik, menurunnya pendapatan yang menyebabkan hilangnya prestise, hidup terpisah dengan anak, terlantar, kurangnya dukungan keluarga. Hal ini bisa memicu stress pada lansia. Ketegangan dari fisik, psikis, emosi maupun mental adalah bentuk stres. Kinerja seseorang sangat dipengaruhi oleh bentuk ketegangan ini. Akibat stres adalah produktivitas menurun, rasa sakit dan juga gangguan mental. Stresor dan tegangan adalah sumber stress dan strain disebut sebagai akibat dari stress. Kesejahteraan emosional seseorang sangat dipengaruhi oleh stress. Sumber stresor dapat berasal dari internal (diri sendri) dan ekstrernal (keluarga, masyarakat, dan lingkungan), (A. aziz Alimul H.2006). Stres tingkat berat bisa menyebabkan lumpuh bahkan kematian (Tay Swee Noi dan Peter J. Smith, 1991). Penilaian individu terhadap stresor akan mempengaruhi individu untuk melakukan tindakan pecegahan terhadap stresor yang membuat stres (Safari dan Saputra, 2009) Stres yang terjadi pada lansia 
harus segera diatasi dan secepatnya untuk di cegah, karena jika ditangani dengan cepat, maka akan menyebabkan kematian. Dalam mengatasi dan menurunkan stres yang terjadi pada lansia pengobatannya tidak harus mahal. Menurut peneliti Graff (2007) salah satu cara dalam pengembalian fungsi mental seseorang atau pada lansia adalah dengan menggunakan terapi Tertawa. Terapi yang bisa menyebabkan kegembiraan di dalam hati yang dikeluarkan melalui mulut dalam bentuk suara tawa, senyuman yang menghias wajah, perasaan hati yang lepas dan bergembira, dada yang lapang, peredaran darah yang lancar sehingga bisa mencegah penyakit, memelihara kesehatan, serta menghilangkan stress disebut terapi tertawa (Robinson, 1990; Dahl dan O'Neal, 1993). Selain itu. Tertawa dapat mengurangi kadar hormon tertentu, yaitu kortisol, epinephrine dan dopac, yang berhubungan dengan respon stres. Tertawa bisa meringankan stres, depresi, kecemasan, kesedihan dan kemarahan, dan juga mengurangi rasa sakit karena bisa memicu pelepasan hormon endorphin. Peningkatan kadar oksigen dalam darah dan peningkatan kapasitas paru juga bisa dipengaruhi oleh tertawa. Akan tetapi menurut Hulse (1994) terapi tertawa tidak boleh diberikan pada klien dengan wasir akut, sesak napas, pascaoperasi, hamil, flu, TBC, dan glukoma. Langkah pertama dalam prosedur terapi tertawa dimulai dengan pemanasan yakni dengan cara menghirup napas melalui hidung, tahan napas selama 15 detik dengan pernapasan perut, lalu hembuskan secara perlahan melalui mulut. Hal kemudian yang dilakukan adalah tertawa lebar (haa-haa-hii-hiihuu-huu). Lakukan sehari 1-2 kali dan 3-4 kali seminggu sehingga di dapatkan manfatnya.

Tujuan penelitian ini adalah untuk mengetahui pengaruh Terapi Tertawa terhadap Tingkat stres pada lansia di RW 06 kelurahan Darmo Surabaya.

\section{BAHAN DAN METODE}

Berdasarkan tujuan penelitian, rancangan penelitian yang digunakan dalam penelitian ini adalah bersifat pra - experimental (one - grup pre - post test design). Populasinya adalah lansia di RW 6 kelurahan Darmo Surabaya sebanyak 20 orang, sampel yang diambil dari sebagian lansia yang di RW 6 kelurahan Darmo Surabaya 19 orang. Penelitian ini menggunakan simple random sampling Instrument penelitian ini menggunakan lembaran Kuisioner Tingkat Stress, Jika Nilai 20-29 = Kebal terhadap stres, jika nilai 30 - 50 $=$ Kurang kebal terhadap stres, jika nilai $51-$ $80=$ Tidak kebal terhadap stres, jika nilai $>80$ Sangat tidak kebal terhadap stres Pada penelitian ini para responden dilakukan intervensi terapi Tertawa selama $3 \mathrm{x}$ seminggu (5-10 menit),.Berikutnya dilakukan intervensi terapi Tertawa selama 3x minggu (5-10 menit selama kegiatan terapi tertawa) dan dari hasil sampel sebanyak 19 orang, Setelah dilakukan intervensi kemudian dilakukan observasi perbedaan tingkat stres masing - masing responden per harinya (post test atau observasi setelah dilakukan tindakan). Kemudian masukan kedalam tabel observasi. Apabila data pre dan post terapi Tertawa sudah terkumpul seluruhnya maka akan dilakukan uji wilcoxon untuk menentukan adanya pengaruh atau tidak.

\section{HASIL}

Distribusi responden berdasarkan jenis kelamin

\begin{tabular}{cccc}
\hline No & Jenis & Jumlah & Persentas \\
& Kelamin & $(\mathrm{n})$ & $(\%)$ \\
\hline 1 & Perempuan & 19 & $100 \%$ \\
2 & Laki-Laki & 0 & $0 \%$ \\
& TOTAL & $\mathbf{1 9}$ & $\mathbf{1 0 0 \%}$ \\
\hline
\end{tabular}

Distribusi responden berdasarkan pekerjaan

\begin{tabular}{cccc}
\hline No & Pekerjaan & $\begin{array}{c}\text { Jumlah } \\
(\mathrm{n})\end{array}$ & $\begin{array}{c}\text { Persentase } \\
(\%)\end{array}$ \\
\hline 1 & Swasta & 3 & $15.8 \%$ \\
2 & PNS & 3 & $15.8 \%$ \\
3 & Tidak & 113 & $68.4 \%$ \\
& Bekerja & & \\
& Total & 19 & $100 \%$ \\
\hline
\end{tabular}

Distribusi responden berdasarkan umur

\begin{tabular}{cccc}
\hline No & Umur & Jumlah (n) & $\begin{array}{c}\text { Persen } \\
(\%)\end{array}$ \\
\hline 1 & $60-74$ tahun & 15 & $78,9 \%$ \\
2 & $75-80$ tahun & 4 & $21,1 \%$ \\
3 & $>80$ tahun & 0 & $0 \%$ \\
4 & Total & 19 & $100 \%$ \\
\hline
\end{tabular}


Distribusi responden berdasarkan tingkat Pendidikan

\begin{tabular}{cccc}
\hline No & Pendidikan & $\begin{array}{c}\text { Jumlah } \\
(\mathrm{n})\end{array}$ & $\begin{array}{c}\text { Persen } \\
(\%)\end{array}$ \\
1 & SD & 4 & $21,01 \%$ \\
2 & SMP & 4 & $21,01 \%$ \\
3 & SMA & 8 & $42,1 \%$ \\
4 & PT & 3 & $18,8 \%$ \\
& Total & 19 & $100 \%$ \\
\hline
\end{tabular}

Distribusi responden berdasarkan tingkat kecemasan sebelum terapi tertawa

\begin{tabular}{ccc}
\hline Tingkat stres & frekuensi & Persentase(\%) \\
\hline kebal & 0 & $0 \%$ \\
Kurang kebal & 5 & $26,3 \%$ \\
tidak kebal & 14 & $73,7 \%$ \\
Sangat kebal & 0 & $0 \%$ \\
Total & $\mathbf{1 9}$ & $\mathbf{1 0 0} \%$ \\
\hline
\end{tabular}

Distribusi responden berdasarkan tingkat kecemasan setelah terapi tertawa

\begin{tabular}{lll}
\hline Tingkat stres & frekuensi & Persentase\% \\
\hline kebal & 6 & $31.6 \%$ \\
Kurang kebal & 12 & $63.1 \%$ \\
tidak kebal & 1 & $5.3 \%$ \\
Sangat kebal & 0 & $0 \%$ \\
Total & $\mathbf{1 9}$ & $\mathbf{1 0 0 \%}$ \\
\hline
\end{tabular}

Distribusi responden berdasarkan tingkat kecemasan sebelum dan setelah terapi tertawa

\begin{tabular}{|c|c|c|c|c|}
\hline $\begin{array}{l}\text { Terapi } \\
\text { Tertawa } \\
\text { Tingkat } \\
\text { Stress }\end{array}$ & $\begin{array}{l}\text { Se } \\
\text { bel } \\
\text { um }\end{array}$ & $\begin{array}{l}\text { Perse } \\
\text { ntasi }\end{array}$ & $\begin{array}{l}\text { Sesud } \\
\text { ah }\end{array}$ & $\begin{array}{l}\text { Perse } \\
\text { ntase }\end{array}$ \\
\hline Kebal & 0 & $0 \%$ & 6 & $31,6 \%$ \\
\hline $\begin{array}{l}\text { Kurang } \\
\text { Kebal }\end{array}$ & 5 & $26,3 \%$ & 12 & $\begin{array}{l}63,1 \\
\%\end{array}$ \\
\hline $\begin{array}{l}\text { Tidak } \\
\text { Kebal }\end{array}$ & 14 & $73,7 \%$ & 1 & $\begin{array}{l}5,3 \\
\%\end{array}$ \\
\hline $\begin{array}{l}\text { Sangat } \\
\text { Kebal }\end{array}$ & 0 & $0 \%$ & 0 & $0 \%$ \\
\hline Total & 19 & $100 \%$ & 19 & $\begin{array}{l}100 \\
\%\end{array}$ \\
\hline Iasil L & & $\mathbf{p}=$ & at & $<0,05$ \\
\hline
\end{tabular}

\section{PEMBAHASAN}

Pada hasil penelitian berdasarkan tabel tentang distribusi data tingkat stres sebelum dilakukan terapi tertawa. Seluruh responden memiliki tingkat stres kurang kebal dengan jumlah responden 20 orang (100\%). Gangguan pada tubuh dan pikiran pada seseorang yang disebabkan oleh perubahan dan tuntutan kehidupan, yang dipengaruhi oleh lingkungan maupun penampilan individu di dalam lingkungan disebut stress (Sunaryo, 2004). Berdasarkan tabel tentang jenis kelamin yang keseluruhan respondennya berjenis kelamin perempuan 20 orang $(100 \%)$. Laki-laki mengalami stress lebih kecil 3 kali disbanding perempuan (Woman Health, 2009). Hal ini disebabkan oleh faktor biologis, yaitu neurotransmitter serotonin yang berpengaruh terhadapa terjadinya stres pada seseorang, dimana otak laki - laki dan perempuan memiliki kemampuan yang berbeda dalam menghasilkan hormone serotonin. Otak lakilaki dan perempuan mempunyai kadar serotonin yang seimbang pada keadaan normal, serotine yang dihasilkan otak laki-laki lebih cepat $52 \%$ dari otak perempuan, hal inilah yang menjadi penyebab perempuan lebih cepat mengalami stres, jika dikaitkan antara fakta dan teori hal ini terjadi karena seluruh responden yang berada di Rw 06 Keluran Darmo surabaya adalah lansia yang berjenis kelamin perempuan, yang sebagian sudah tidak bekerja, yang aktivitasnya hanya makan, nonton TV, berdoa. Karena aktivitas yang kurang inilah yang menyebabkan menurunnya kadar serotonin dalam otak sehingga lansia tersebut mengalami stres.

Berdasarkan tabel tentang usia responden jumlah responden yang banyak adalah umur 60-74 tahun sebanyak 16 orang (80\%), dan responden yang paling sedikit yaitu umur 75 89 tahun dengan jumlah 4 orang (20\%). Menurut Tamber, S - Noorkasiani, 2009 semakin bertambahnya umur manusia akan terjadi proses penuaan secara regeneratif yang berdampak pada perubahan-perubahan fisik, kognitif, social dan seksual. Lansiapun termasuk yang mengalami perubahan itu. Salah satu masalah psikologis yang dialami lansia adalah stres dan dengan bertambahnya usia seseorang, semakin siap pula dalam menerima cobaan, jika dikaitkan antara teori dan kasus nyata maka akan diketahui semakin tua umur seseorang, maka orang tersebut akan mengalami banyak perubahan, entah itu perubahan yang dialami diri sendri atau yang 
terjadi dilingkungannya atau orang terdekatnya yang membuat tingkat stres lebih tinggi terjadi pada usia lanjut atau lansia.

Pada penelitian ini responden paling banyak memiliki tingkat pendidikan rendah yaitu sekolah menengah atas (SMA) sebanyak 9 orang (45\%). Menurut Stuart dan Studden, 2010 Pendidikan yang rendah akan menyebabkan orang tersebut mudah mengalami kecemasan dan stres yang berlebihan, tingkat pendidikan juga berperan dalam hal ini. Semakin tinggi pendidikan seseorang, emakin banyak pengelaman hidup yang dilaluinya, sehingga akan lebih siap dalam menghadapi masalah yang terjadi, jika dikaitkan antara teori dan kasus nyata maka semakin rendah tingkat pendidikan atau yang berpengetahuan kurang luas semakin susah bagi seseorang tersebut untuk mendapatkan pikiran yang rasional dan logis, sehingga dapat dikatakan pengetahuan para responden sangat minim oleh karena itu mereka menerima masukan dari orang yang berpendidikan lebih tinggi akhibatnya para responden dapat menyakini bahwa terapi tertawa yang dilakukan responden mampu menurunkan tingkat stres yang dialami. Hal ini dapat menunjukan bahwa para responden sangat kooperatif dengan tindakan yang dilakukan oleh peneliti.

Pada penelitian ini sebagian besar responden, sebelum masuk pada lansia di rw 06 mereka memiliki pekerjaan PNS 3 orang $(15 \%)$ dan wiraswasta 3 orang (15\%). Dengan bekerja seseorang dapat menghilangkan kebosanan dan bersosialisasi, sehingga dapat mengurangi stres. Stress yang timbul dapat muncul dari rasa bosan serta ketidak berdayaan, jika dikaitkan antara kasus nyata dan teori apabila seorang bekerja dan mendapatkan penghasillan maka orang tersebut akan merasa berguna bagi orang lain, khususnya bagi dirinya sendri, sedangkan jika tidak bekerja orang tersebut akan merasa tidak berdaya dan menggatungkan diri pada orang lain, dan kegiatan yang dilakukan juga sedikit sehingga menimbulkan rasa bosan dan dapat membuat orang tersebut stres.

Berdasarkan tabel tentang tingkat stress responden yang mengalami perubahan menjadi kategori stres kurang kebal sebanyak 11 orang
(55\%). Hasil tersebut menunjukan bahwa terjadi penurunan tingkat stres setelah dilakukan terapi tertawa. Terapi tersebut untuk mencapai kegembiraan di dalam hati melalui mulut dalam bentuk suara tawa, senyuman yang menghiasi wajah, perasaan hati yang lepas dan gembira, dada yang lapang, peredaran darah yang lancer sehingga bisa mencegah penyakit, memelihara kesehatan serta menghilangkan stress disebut terapi tertawa (Menurut (Robinson, 1990; Dahl dan O’Neal, 1993)

Berdasarkan hasil penelitian dikaitkan dengan teori diatas maka didapatkan bahwa terapi tertawa berpengaruh pada tingkat stres pada lansia, responden seluruhnya mengalami perubahan menjadi kategori kurang kebal sebanyak 11 orang $(55 \%)$ dan yang mengalami penurunan kategori tidak kebal sebanyak 1 orang $(5 \%)$, hal ini disebabkan oleh pelaksanaan terapi tertawa yang benar dan tepat yaitu selama 4 hari (5-10 menit/hari) sehingga dapat membuat lansia merasa berguna dengan kreatifitas yang dibuatnya, namun keberhasilan terapi Tertawa yang penulis lakukan pada responden tidak lepas dari kepatuhan responden dimana responden benar - benar percaya bahwa tindakan ini dapat membantu proses penurunan tingkat stres pada responden, sehingga pengetahuan tentang terapi Tertawa terhadap tingkat stres sangat minim oleh sebab itu responden menaruh kepercayaan yang sangat besar kepada peneliti dan responden merasa nyaman sehingga diyakini mampu menurunkan tingkat stres yang dialami.

Berdasarkan data distribusi tabel tentang tingkat stress dapat diketahui bahwa semua responden yang diteliti memilki kategori tingkat stres sedang sebelum dilakukan terapi tertawa sebanyak 20 orang (100\%) dan setelah dilakukan terapi tertawa didapatkan semua responden mengalami kurang kebal terhadap stres sebanyak 11 orang $(55 \%)$ dan yang masuk kedalam kategori tidak kebal sebnyak 1 orang $(5 \%)$. Berdasarkan uji statistik wilcoxon yang didapatkan, bahwa nilai $\mathrm{p}<0,05$ sedangkan hasil yang diperoleh yaitu $\mathrm{p}=0,008$ dengan demikian $\mathrm{H} 0$ ditolak dan $\mathrm{H} 1$ diterima yang memiliki arti ada pengaruh penerapan 
terapi Tertawa terhadap tingkat stres pada lansia di rw 06 Kelurahan Darmo Surabaya.

Berdasarkan hasil penelitian yang dilakukan peneliti, dari item - item masalah atau kejadian yang dialami menurut skala Miller dan Smith, ada beberapa item yang mengalami perubahan diantaranya adalah perubahan pola tidur, perubahan pola Aktivitas keagamaan,sendirian di hari libur, Menurut Alimul, aziz (2012) kebutuhan tidur pada tingkat perkembangan masa dewasa tua yaitu $6 \mathrm{jam} /$ hari,dengan tujuan dan fungsi tidur untuk menjaga keseimbangan mental, emosional, kesehatan, dan mengurangi stres, jika dikaitan dengan teori dan kasus nyata sebelum dilakukan terapi Tertawa lansia di rw 06 hampir keseluruhan mengalami susah tidur hal ini dikarenakan mindset bahwa saya tidak bisa tidur, dan ada rasanya cemas memikirkan hari tuanya, dan setelah dilakukan terapi Tertawa lansia diberi arahan, jika susah tidur lansia dapat melakukan salah satu jenis kegiatan terapi tertawa yang telah peneliti ajarkan (Tawa Sapaan) yang nantinya dapat memancing rasa ngatuk untuk segera beristirahat. Pada perubahan aktivitas keagamaan menurut Alimul, Aziz (2012), menjelaskan bahwa adanya macam - macam distress spiritual, salah satunya adalah spiritual yang sakit, yaitu tidak dapat menerima kehilangan orang terdekat yang disayangi. Ada keterkaitan antara teori dan kasus pada lansia di RW 06 Kelurahan Darmo dimana masih merasakan kehilangan dari orang yang mereka cintai walaupun itu sudah bertahun - tahun lamanya, dengan adanya terapi Tertawa lansia diajak untuk melakukan kegiatan terapi Tertawa (Tawa sapaan, Tawa bantahan) sehingga lansia dapat melakukan aktivitas keagamaannya dengan perasaan yang tenang. Secara umum dengan bertambahnya usia akan menurunkan kekuatan dan kualitas fisik juga psikologis. Stres merupakan bentuk ketegangan fisik, psikis, emosi maupun mental. Kinerja keseharian seseorang dapat dipengaruhi oleh ketegangan ini, terlebih pada orang tua. Sejauh ini banyak orang tua yang belum mengetahui terapi untuk menurunkan tingkat stres yang ada pada dirinya. Cara non farmakologi dapat dilakukan untuk terapi tertawa, pasien diamati dan dievaluasi saat beraktivitas, juga ada penilaian terhadap hasil pekerjaan. Hal tersebut dapat memenetuhkan arah terapi dan rehabilitasi selanjutnya dari pasien tersebut. Penting untuk diingat terapi Tertawa tidak untuk menyembuhkan, tetapi hanya sebagai media, dengan dilakukannnya terapi Tertawa perubahan tingkat stres yang mereka alami sangat bervarian, semua responden mengalami penurunan tetapi, masih dalam kategori sedang. Tingkat stres mengalami perubahan yang mengarah ke lebih baik, akan berpengaruh pada pola aktivitas mereka untuk mempertahankan stres, sehingga secara perlahan terapi Tertawa dapat sebagai terapi alternative non farmakologi dalam membatu mengurangi tingkat stres, dengan kata lain responden mampu melakukan terapi Tertawa secara mandiri serta dapat mengurangi angka peningkatan stres yang terjadi pada lansia.

\section{SIMPULAN}

Tingkat stres pada lansia sebelum dilakukan terapi tertawa di RW 06 kelurahan Darmo Surabaya, dengan kategori tidak kebal sebanyak 14 orang $(73,7 \%)$.

Tingkat stres pada lansia sesudah dilakukan terapi Tertawa di RW 06 Kelurahan Darmo Surabaya, dengan kategori kurang kebal sebanyak 12 orang $(63,1 \%)$.

Ada pengaruh penerapan terapi Tertawa terhadap tingkat stres pada lansia di RW 06 kelurahan Darmo Surabaya.

\section{DAFTAR PUSTAKA}

Alimul Aziz. 2006. Pengantar Kebutuhan Dasar Manusia. Jakarta: Salemba Medika.

Alimul Aziz. 2008. Pengatar Konsep Dasar Keperawatan. Edisi 2. Jakarta: Salemba Medika.

Dalami Ermawati. 2010. Konsep Dasar Keperawatan Jiwa. Jakarta: TIM.

Kushariyadi Settyoadi. 2011. Terapi Modalitas Keperawatan Pada Klien Psikogeriatrik. Jakarta: Salemba Medika.

Maryam Sity, Mia Fatma Ekasari.Dkk. 2008. Mengenal Usia Lanjut Dan Perawatannya. Jakarta: Salemba Medika.

Alimul Aziz. 2007. Metode Penelitian Keperawatan dan Teknik Analisa Data. Jakarta: Salemba Medika. 
Nursalam. 2011. Kosep Dan Penerapan Metodologi Penelitian Ilmu Keperawatan Pedoman Skripsi, Tesis Dan Isntrumen Penelitian Perawatan. Jakarta: Salemba Medika.

Padila. 2013. Keperawatan gerontik. Yogjakarta: nuha medika

Ponto, Bidjuni, Karundeng. 2015. Jurnal Pengaruh Penerapan Terapi tertawa Terhadap tingkat Stres Pada Lansia Di Panti Werda Damai Ranouut Manado. Manado Universitas Sam Ratulangi. Diakses pada tanggal 23 oktober pkl 10.30 WIB 